\title{
Motivation and Personality Traits of TESL Postgraduate Students towards the Use of Information and Communications Technology (ICT) in Second Language Teaching
}

\author{
Vahideh Hassanzadeh (Corresponding author) \\ Master Student of TESL, Faculty of Educational Studies, Universiti Putra Malaysia (UPM), Malaysia
}

Tel: 60-17-200-4913 E-mail: Vahideh_2010@yahoo.com

Reza Gholami

PhD Student of TESL, Faculty of Educational Studies, Universiti Putra Malaysia (UPM), Malaysia

Tel: 60-11-1541-8046 E-mail: gholami.phd@hotmail.com

Negah Allahyar

PhD Student of TESL, Faculty of Educational Studies, Universiti Science Malaysia (USM), Malaysia

Tel: 60-12-312-6143 E-mail: negah.al@gmail.com

Nooreen Noordin

Senior Lecturer, Faculty of Educational Studies, Universiti Putra Malaysia (UPM), Malaysia

Tel: 60-13-667-0573 E-mail: Nooyeen@yahoo.com

Received: January 1, 2012

doi:10.5539/elt.v5n4p74
Accepted: February 11, 2012

Published: April 1, 2012

\begin{abstract}
Nowadays technology has practically changed every aspect of language teaching. There are numerous studies focusing on the personality traits of students or other internet users towards the internet utilization. Nonetheless, little research has examined the personality traits of teachers towards using computers for educational purposes especially in the Malaysian context. The purpose of this study was to investigate the motivation and personality traits of TESL postgraduate students in Malaysia towards information and communications technology (ICT) usage in second language teaching. In addition, the relationships between the independent variables (motivation, and personality traits) and the dependent variable (ICT usage) were explored. Then a descriptive-correlational research was employed. A questionnaire survey was developed, reviewed by a panel of experts and its validity and reliability were verified through a pilot study. For the survey, 89 TESL postgraduate students were randomly selected. Moreover, follow-up semi-structured interviews were conducted to strengthen the questionnaire survey results. The results indicated that English teachers have high levels of ICT utilization in the general software applications such as Internet, E-mail, presentation, word processing and office work and low levels of ICT usage for specialized software applications such as authoring, graphics and simulations. The results also showed that the participating teachers were highly motivated in teaching language with computers. Furthermore, the results related to the participants' personality traits indicated that they were highly extrovert, agreeable, conscientious, open and moderately neurotic towards ICT usage. The findings of correlation analysis proved that the surveyed teachers' motivation received a slightly moderate and positive relationship with ICT usage. Additionally, the findings of the Pearson correlation coefficient for the relationship between teachers' personality traits and ICT usage showed that generally no correlation exist between the overall personality and ICT usage. In particular the findings showed that only extroverts had a slightly moderate and positive correlation with ICT usage. The interviews responses also verified the questionnaire results. The research results suggest that to develop ICT integration in the educational processes, teacher training computer skills and increasing the computer facilities at schools are required. Finally, implications, and recommendations for future research are discussed.
\end{abstract}

Keywords: ICT, Motivation, Personality, Big Five, English Teachers 


\section{Introduction}

ICT provides the basic technology for assisting language teaching/learners to acquire important communication skills in English language. Kleiman (2000) asserts that computers can facilitate teaching and learning processes in all fields and all levels. Moreover, ICT creates a rich learning environment using diverse materials mainly for the second/foreign language acquisition (Pusack \& Otto, 1997). In Malaysia, the place where this study was carried out, the chief foreign language is English which is practically used in all parts of daily life. In both primary and secondary schools in Malaysia, English is taught as a compulsory subject. Because of the importance of English, the Malaysian government has required the Mathematics and Science teachers to teach these two subjects in English since 2003. To assist these teachers in their teaching profession, the government gave the teachers laptops and required teaching courseware and equipped the classrooms with technological facilities.

Technology has a pivotal role in teachers and students' practices such as promoting collaborative learning, improving communication skills, enhancing teachers and students' motivation through diverse activities and updated information as well as increasing learners achievement due to the reinforcement and various practices provided in the Internet (Warschauer, \& Healey, 1998; Downes, , Arthur, \& Beecher, 2001). In addition, teachers have essential effects on technology adoption in the classroom (Kidd and Song 2005). Becker (2000) points out that teacher related factors to ICT adoption are the most influential predictors. Afshari, Bakar, Su-Luan, Samah and Fooi (2009) identified some factors including teachers' technology literacy as well as their attitude and motivation towards technology usage. Moreover, Tonelson (1981) and Aydin (1998) assert that the teachers' personalities influence their students' learning achievements and play an important role in the students' success. Chan (2001) found that the high extrovert teachers were more effective in the classroom practices. Although this might be true in some instances, there exists a contradiction between the predictions of psychologists and applied linguists in respect to the relationship between extroversion and learning or teaching in general. There is still a debate to know which personality type is in advantage (Kiany, 1997). In terms of computer technology, Smith and Munday (1995) considered personality as a predictor of teachers' willingness towards computer integration in the classrooms. Since technology has a critical role in the educational activities, the identification of teachers' personality and motivation towards computer technology usage would be valuable as there is also scarcity of studies relating teachers' personality and motivation in adopting the computer technology.

The theoretical framework of this research is the 'Big Five' Model of Personality. Human personality can be investigated under five factors: extroversion, agreeableness, conscientiousness, openness, and neuroticism which ultimately became identified as the 'Big Five' (Goldberg 1981). Based on the 'Big Five' Model, and reviewing prior studies, the aim of this study is to identify the TESL postgraduate students' motivation and personality traits on ICT integration in the second language teaching.

The major goal of Malaysian Vision 2020 is to become a fully developed country by the year 2020 (The Malaysian Dream: Vision 2020). Following this plan, the major sectors of Malaysian society including governance, healthcare, commerce, education and manufacturing were determined to use IT. One of the projects in education sector was the Smart School project whose goal is to prepare children for the Information Age. However, studies have shown that with lots of efforts of Malaysian government to equip schools with computer facilities and to enhance teachers computer literacy and technology adoption, teachers are not adequately ready to integrate technology in the learning environments and do not uptake ICT to its fullest potential (Lee, 2000; Sathiamoorthy, 2001; Chong, Sharaf \& Jacob, 2005; Yusof, Taib, and Adnan, 2010). This study attempts to unveil teachers' level of ICT use in English language teaching and evaluate their motivation and personality towards technology adoption. The findings of this research may shed light on the teachers' motivation and personality traits toward technology application.

\subsection{Statement of the Problem}

Technology integration into language education has some significant effects on instructors and pupils such as enhancing the cooperation with colleagues, increasing the motivation, enabling more student-centered teaching, and also developing the thinking skills and problem solving tasks. Even though teachers are aware of these advantages, the utilization of computers to teach English language is still very negligible. Several studies have indicated that school teachers employ computers not for educational tasks, but apply ICT only for preparatory and administrative activities. Only a small number of teachers apply the educational software in the primary and secondary schools (Cuban, 2001). A number of studies have revealed that although Malaysian government has attempted to boost technology adoption, teachers are insufficiently ready to integrate technology in the learning environments and do not uptake Information and communication technology (ICT) to its fullest potential.

As motivation is a significant element in ICT utilization, some researchers evaluated teachers' motivation and their findings revealed that the majority of the teachers had a positive motivation towards technology usage in teaching 
and learning practices (Nurul Atikah Abdullah, Zainol Abidin, Wong Su Luan \& Atan, 2006; Melor, 2007b). A study done by Abdul Razak, and Sanmugam, (2010) indicated that the Internet services create positive attitude and high motivation among the English teachers in the ESL environment. Hence, this high motivation makes a tension free setting for the learners while learning English. In addition, computer usage makes the English lessons more interesting, exciting and effective. However, these studies were carried out with undergraduate students while no study has been done on the postgraduate students' level of ICT usage and their motivation to utilize technology which in fact urged the authors of this study to examine the fact about postgraduate students' level of ICT usage and their motivation toward technology.

Personality is a significant factor that affects teachers' behaviours to utilize technology in education. It is believed that there is a contradiction between the predictions of psychologists and applied linguists in respect to the relationship between extroversion and learning or in general. Yet, it is not clearly known which personality type is in advantage (Kiany, 1997). Such beliefs that extroversion may help or hinder developing second/foreign language skills as Stern (1983) maintains may be only half-truth, but they provide the stimulus for systematic investigations such as this current research. Teachers with different personalities show different willingness towards computer usage (Katz \& offir, 1991). Therefore, because of the dissimilarities among teachers, they will be different in ICT adoption (McKenzie, 1993; Passey and Samways, 1997). In reviewing the literature, several studies have been carried out to investigate the personality traits in relation to internet utilization of the students and other internet users (e.g., Hamburger \& Ben-Artzi, 2000; Scealy, Phillips, \& Stevenson, 2002; and Ross et al., 2009). But very few studies, as yet, were found focusing on the motivation and personality of teachers associated with ICT usage (Katz 1984cited in Katz and Offir 1991, 249) and Perkmen \& Cevik (2010) especially among English teachers in Malaysia. Few studies have examined the personality and motivation of teachers in computer technology application (Perkmen, and Çevik, 2010). The limitation of this study, however, is the lack of information regarding personality and motivation to computer use by English education teachers in Malaysia. Hence, this research study focuses on this gap in the literature by illustrating how ESL teachers utilize their computer knowledge and skills on combination of ICT in their classrooms. Particularly, this research examines the teachers' personality traits and motivation in applying the ICT in teaching practices.

\subsection{Research Questions}

Based on the Big Five Model of Personality, this study aims to investigate the overall levels of pre-service teachers' motivation towards CAI and their relation to personality. To help meet this aim, five research questions were addressed.

1. What is the level of ICT usage by TESL postgraduate students in second language teaching?

2. What is the level of motivation of TESL postgraduate students towards ICT usage in second language teaching?

3. Which dimension of personality traits the TESL postgraduate students have towards ICT usage in second language teaching?

4. Is there any significant relationship between the TESL postgraduate students' level of motivation and their use of ICT in second language teaching?

5. Is there any significant relationship between TESL postgraduate students' personality traits and their use of ICT in second language teaching?

\section{Related Literature Review}

\subsection{ICT in Education}

Regarding the Malaysian Vision 2020 to transform from an industrial economy to a knowledge-based community, the Ministry of Education enforced a number of ICT programs in schools all over the country to implement the technology into the classrooms. One of the main projects in the education system of Malaysia was the Smart School project which is in fact a learning institution that reconstructs the teaching-learning and school management processes systemically to assist students and schools to cope with the information age and also to promote the goals of the National Philosophy of Education (Smart School Task Force, 1997). Because of the language teachers' familiarity with English as the main language of the software and ICT, the field of foreign language education has always been in the forefront of ICT usage to facilitate the language acquisition process. Therefore, language teachers by altering their practices and beliefs towards ICT usage can obtain the positive effects of the new teaching method on quality of learning outcomes. Boswood (1997) argued that computer resources and tools can be employed in several ways to promote the language education; for instance, word processing programs develop learners' skills in creating, storing, and editing written tasks; e-mail involves pupils in corporative learning tasks with peers and teachers within and outside of schools; using the Internet in searching, and gathering information; language practice 
such as exercises with multimedia CDROMs; and the World Wide Web is a necessary source for presenting authentic materials to practice language patterns.

\subsection{Motivation to Use ICT}

Dusick (1998) declares that teachers' motivation is interrelated with their ICT usage in the classroom. Motivation as a personal variable is a significant factor pertinent to teachers' uptake of ICT in the classroom (Marcinkiewicz, 1996 and Cox, Preston, \& Cox, 1999). McNabb (1999) believes that motivation is one of the major components in creating a positive environment for teachers and learners to explore new ways of learning. Abdul Razak and Sanmugam (2010) examined Malaysian teacher trainees' attitude and motivation in teaching English by the Internet resources and found positive effects among those variables. The findings indicated that teaching ESL through the Internet is interesting, enjoyable and fun. Accordingly, the internet can motivate teachers to be confident in their teaching activities. Majority of the studies have confirmed that the Internet enhances the teachers' level of motivation. Lumley (1991), as an example, noted that teachers who use the technology to motivate students are more powerful and productive than the ones who simply use lectures and textbooks.

\subsection{Personality to Use ICT}

Ryckman (2004) described personality as a dynamic and organized set of traits possessed by an individual that uniquely affects on his/her motivations, cognitions and behaviors in diverse conditions. In the personal facets, a fundamental psychological mechanism which manages individuals' behaviours is called personality (Halder, Roy and Chakraborty 2010 as cited in Teh, Yong, Chong, \&Yew, 2011). Thus, personality is a key factor that influences the persons' behaviours in utilizing the technology.

\subsection{Theoretical Framework: Big Five Model of Personality}

The "Big Five" model illustrates individuals' personality traits in the psychology domain. As Denissen and Penke (2008) pointed out, the Big Five model summarizes the major characteristics of individual's personality into five central descriptors which classify the diverse human behaviours into an organized taxonomy. Thus, the intent of the research based on the "Big Five" Model of Personality is to weigh the English postgraduate students' motivation and personality traits to use ICT. This model was selected as a theoretical framework of this study for two reasons: primarily, this model has been validated by numerous studies (Costa 2000; Judge, Thoresen, Bono, \& Patton, 2001; Lounsbury, Steel, Loveland, \& Gibson, 2004; Furnham, Dissou, Sloan, \& Chamorro-Premuzic, 2007) and this model has achieved broad acceptance in the last two decades. The five factor model has proven to be a robust model of measurement and study for a range of human behaviors. This model includes five broad dimensions of personality traits as follow:

- Agreeableness refers to compassion and a willingness to participate, conform, and cooperate with others. Agreeable persons are cooperative and forgiving as well as sympathetic and good-natured (Judge, Higgins, Thoresen \& Barrick, 1999).

- Conscientiousness represents the tendency to be self-disciplined, strong-willed, deliberate, trusty, organized and reliable. Conscientious people actively plan, organize, and carry out tasks. Conscientiousness is the trait that has been drawn upon as a main psychological resource in situations where achievement is an important value; those situations are especially contexts of work, learning and education (De Raad, 2000).

- Extroversion represents sociability, gregarious, cheerfulness, and optimism. Extraverts seek out new opportunities and excitement. It is a tendency to seek social stimulations in the company of others. "Extroverts are more sociable, and active but are also described as being more active and impulsive, less dysphoric, and as less introspective and self-preoccupied than introverts"( Wastson and Clark, 1997, p.769).

- Neuroticism or emotional instability is the tendency to experience unpleasant feelings such as anger, anxiety, fear, and depression. Highly neurotic people tend to be embarrassed, sad, distrustful, and have difficulty managing stress (Judge, Higgins, Thoresen \& Barrick, 1999) and lack self-confidence and self-esteem (McCrae \& Costa, 1991).

- Openness to experience represents one's curiosity, creativity, imagination and willingness to explore new ideas (Judge \& Bono, 2000). "Open individuals tend to devise novel ideas, hold unconventional values and willingly question authority" (Costa \& McCrae, 2000, p. 325). People who score high on the openness factor engage the world with a spirit that is eager and keenly interested (Beck, 1999).

Devaraj, Easley, and Crant (2008) showed in their research that there was a positive relationship between personality, technology usage and acceptance and online behaviour. Their findings revealed that people high in agreeableness and conscientiousness traits are more likely to perceive usefulness of new technology, while individuals high in neurotic traits are less likely to perceive the usefulness of new technologies. Neuroticism aggravates problems 
experienced in approaching and using computers and extroversion alleviates them (Hudiburg, 1999). Hamburger and Ben-Artzi (2000) found that extroversion and neuroticism were related to different types of Internet usage. Overall, personality refers to the all aspects of a human's individuality and research in personality shows that personality does make a difference in a teacher's willingness to use technology. For example, Katz (1992) found that extroverted, stable, and tough-minded personalities were more receptive to the use of computers.

\section{Method}

\subsection{Research Design and Participants}

A descriptive approach was used in order to achieve the first three objectives of the study, which are identifying the level of ICT use and the motivation and personality traits to apply ICT in teaching English among TESL postgraduate students. The descriptive approach employed the use of a survey method form of a 73-item questionnaire and a semi-structured interview conducted with the English language teachers. Furthermore, a correlation technique was used to determine the relationships between the ESL teachers' motivation and their level of computer use. Besides, for the last objective, to determine the relationship between each of five personality characteristics of Agreeableness, Conscientiousness, Extroversion, Neuroticism, and Openness, or combination of these five factors, and level of ICT usage, a correlation technique was employed. This study is carried out in one of the universities in Malaysia. Data was collected randomly and 89 out of 102 participants in the study (87\%respose rate) answered the questionnaire completely. Demographic data showed that 71 teachers $(79.8 \%)$ were female, while 18 people were male (20.2\%). (40.4\%), respondents between $26-29$ years old were 28 persons $(31.5 \%)$ and $28.1 \%$ were $22-25$ years old. Most of the respondents were Malay at $43.8 \%$ whereas $25.8 \%$ Chinese and Indian respondents were $30.3 \%$. A majority of participants $68.5 \%$ (61 out of 89 ) were Master of Education students, while $13.5 \%$ were Master of Science and the rest $18 \%$ were PhD students. (61.8\%) 55 people reported that they had received ICT training whereas 34 teachers (38.2\%) had not received any ICT training.

\subsection{Instrumentation}

The Motivation and Personality to Use ICT Questionnaire was developed by modifying the items from different sources. The demographics and motivation sections (section one and three) in the questionnaire was adopted and adapted from Li (2008), the items for level of ICT use (section two) were from adopted and adapted Isleem (2003) and personality traits (section four) adopted and adapted from John (1990). The modified version was reviewed by a panel of experts and was piloted before collecting the data. The reliability of the questionnaire of the study showed that $\mathrm{ICT}=.78$; motivation $=.92$; personality $=.88$; Agreeableness; Conscientiousness $=.74$; Extroversion $=.85$; Neuroticism $=.89$; Openness $=.86$ and overall reliability was 0.93 . The questionnaire was composed of four sections and respondents required approximately 15 minutes to complete it. Its first section is demographics with 6 questions refers to the general information of participants such as gender, age, ethnicity, degree, ICT training and the focus of the training skills. The second, third and fourth sections included Likert-scale items referring to the research questions. In addition, the semi-structured interviews were conducted for further justification and understanding of the collected data from the questionnaires.

\section{Results and Discussion}

Both descriptive and inferential statistics were employed for analyzing the quantitative data of this study. The data collected was processed by using Statistical Package for Social Science (SPSS) version 18.0.

\subsection{Results Related to Question One}

Respondents respond to 14 Likert-scale items measuring their level of ICT use. The results of descriptive analysis (Means, Std. Deviations, and Percentages) are displayed in Table 1.As illustrated in Table 1., the highest Percentages of scores in the use of ICT for teaching English by the subject teachers were Internet (93.3\% "often or "very often", $\mathrm{M}=4.58$ and $\mathrm{SD}=.61)$, E-mail $(92.1 \%$ "often" or "very often", $\mathrm{M}=4.65$ and $\mathrm{SD}=.62)$, presentation $(86.6 \%$ "often" or "very often", $\mathrm{M}=4.35$ and $\mathrm{SD}=.74)$, word processing $(85.4 \%$ "often" or "very often", $\mathrm{M}=4.40$ and SD $=.82)$, and office work (76.4\% "often" or "very often", $\mathrm{M}=4.10$ and $\mathrm{SD}=.96)$. In contrast, the lowest Percentages of ICT utilization by the sample teachers were database program (11.2\% "never", $\mathrm{M}=2.79$ and $\mathrm{SD}=1.08)$, authoring (10.1\% "never", $\mathrm{M}=2.64$ and $\mathrm{SD}=.96)$, and graphics $(10.1 \%$ "never", $\mathrm{M}=2.67$ and $\mathrm{SD}=1.10)$. As shown in Table 1, the mean, Std. Deviation (SD) and the percentages of scores demonstrate that the English language teachers have high levels of ICT usage for teaching practices such as the Internet, E-mail, presentation, word processing and office work. On the other hand, they have low levels of ICT tools such as database program, authoring and graphics. Besides that, the overall mean of teachers' ICT usage was calculated and is $\mathrm{M}=3.63$ and $\mathrm{SD}=.46$. Based on the Table 2, adopted from Gholami, Nooreen Noordin and Ghazali Mustapha (in press), the ICT use Mean $(\mathrm{M}=3.63)$ is high which reveals that the level of computer technology utilization by the TESL 
postgraduate students is high in their teaching processes.

Following the survey and after the data analysis of the questionnaire, the semi-structured interviews were carried out. The interviewees' information was transcribed for analysis processes. Firstly, for further justification of the sample, teachers' perspective on the advantages of ICT usage in language instruction is provided in the following:

1. Being a creative teacher.

2. Paying more attention to lessons.

3. No need to write with chalk on board.

4. Taking teachers' notes via e-mail or Internet.

5. Teaching all the four language skills by using ICT.

6. Using a variety of activities and tasks for students.

It can be concluded that the participants know the benefits of ICT in language teaching and learning and use it in their profession well. Furthermore, the interviewee's comments on the disadvantages of ICT usage in language instruction are reported as follow:

1. Lack of access to computers.

2. Lack of teachers' computer training.

3. Lack of students' computer training.

4. Difficulties in controlling and checking students.

This part shows that despite some barriers in ICT utilization, the English teachers have a positive view towards computer technology usage in teaching activities. The overall mean of ICT usage is high $(\mathrm{M}=3.63$ and $\mathrm{SD}=.46)$ suggesting that computer are frequently used in teaching English. Although this result contradicts the Keong, Horani and Daniel's (2005) study that found the level of ICT use in Mathematics instruction was low, the research findings have indicated that the teachers show high levels of computer technology usage for general software applications such as Internet, E-mail, presentation, word processing and office work. Meanwhile, they have low level of ICT usage for specialized software applications such as authoring, graphics and simulations. These results of this study were supported with the interview findings as well as being supported by Lau and Sim's (2008) research on the 212 Malaysian Mathematics and Science teachers. Overall, this finding offers that schools teachers require training in a wide range of computer technology skills to make full use of ICT in teaching processes.

\subsection{Results Related to Question Two}

Research question two aimed to investigate English teachers' motivation towards use of ICT in language teaching. This part asked the participants to respond 13 Likert-scale items with 5 options $(1=$ Strongly disagree; $2=$ Disagree; $3=$ Undecided; $4=$ Agree; $5=$ Strongly agree). For all survey items in the motivation towards ICT use, mean, standard deviation (SD), minimum, maximum and percentages were calculated and reported in the Table 5. The most frequent positive motivations towards ICT usage were item $3(93.2 \%$ of the respondents reported that they "agree or strongly agree" with that statement), with Mean score $(\mathrm{M}=4.43)$ and Std. Deviation $(\mathrm{SD}=.73)$, item1 (93.2\% "agree or strongly agree" with $\mathrm{M}=4.33$ and $\mathrm{SD}=.72)$, item 7 ( $88.8 \%$ "agree or strongly agree" with $\mathrm{M}=$ 4.21 and $\mathrm{SD}=.74)$, item 5 (83.1\% "agree or strongly agree" with $\mathrm{M}=4.20$ and $\mathrm{SD}=.86)$, item $4(83.1 \%$ "agree or strongly agree" with $\mathrm{M}=4.14$ and $\mathrm{SD}=.79)$, item $8(82.1 \%$ "agree or strongly agree" with $\mathrm{M}=4.05$ and $\mathrm{SD}=.87)$, item 9 (78.7\% "agree or strongly agree" with $\mathrm{M}=3.97$ and $\mathrm{SD}=89)$, item 11 (76.4\% "agree or strongly agree" with $\mathrm{M}=4.0$ and $\mathrm{SD}=.76)$, item $2(76.4 \%$ "agree or strongly agree" with $\mathrm{M}=3.96$ and $\mathrm{SD}=.91)$, and item $13(76.4 \%$ "agree or strongly agree" with $\mathrm{M}=3.95$ and $\mathrm{SD}=.82)$. The least frequent items in this section were item $6(75.3 \%$ "agree or strongly agree" with $\mathrm{M}=3.96$ and $\mathrm{SD}=.87)$, and item $10(74.1 \%$ "agree or strongly agree" with $\mathrm{M}=3.91$ and $\mathrm{SD}=.79)$, and item $12(64.0 \%$ "agree or strongly agree" with $\mathrm{M}=3.64$ and $\mathrm{SD}=1.02)$. In general, according to table 2, the total mean value of the respondents' motivation towards ICT usage is high ( $\mathrm{M}=4.06$ and $\mathrm{SD}=.60)$.

In order to investigate the teachers' motivation towards using ICT, some of the interviewees' comments are listed as follow:

1. Getting information easily and quickly

2.Learning English becomes more fun

3. Providing an alternative method of teaching 


\subsubsection{Discussion of Question Two}

The main focus of this discussion part is the English teachers' motivation towards computer technology use in teaching language. As seen in Table 3, the most frequent items in the motivation questionnaire selected by the surveyed teachers were items 3 and 1 (93.2\%) which addressed using ICT to communicate with others and also getting useful information, respectively. These findings imply that the language educators use computer technology more for general purposes than direct teaching practices. As illustrated in table 5, a high number of English teachers chose items 7 and 5 (ICT makes lessons fun and interesting). These results are compatible with Cox, et al.'s (1999) findings who carried out a study to identify the factors which motivate teachers to use ICT. Cox, et al. (1999) found that the majority of teachers considered ICT to make learning more fun and interesting. These findings are in parallel to the findings of the study by Efaw, Hampton, Martinez, and Smith (2004) and Li and Walsh (2011). Thus, it means that enjoyment is a great factor that motivates teachers and students in English education. 83.1\% of the respondents stated that ICT helps them to change the way of teaching, (item 4) which might mean they use computer as an alternative to traditional teaching tools. A number of the sample teachers reported through items 8 and 9 that they use ICT activities to teach four main language skills. In response to statements 11, 2, and 13 identically (76.4\%), teachers pointed out that ICT helps them in preparing their students for information society while reducing their workload and providing authentic materials for teaching language. Similarly, Li and Walsh (2011) found that technology allows introducing authentic materials in English language practices and applying computer for presentation tasks reduces teachers' workload, but developing courseware enhances their workload. Item 6 (ICT makes learning easier) was supported by the studies of Cox, et al. (1999) and Efaw, et al. (2004). The least frequent items reported by the participating teachers were items 10 and 12 probably because that they think other conditions needed to be a better teacher or improve speaking confidence than ICT adoption. In general, the overall mean value of the teachers' motivation towards the use of ICT to educate English language was M=4.06 with a Std. Deviation $(\mathrm{SD})=0.60$ (Table 2). Accordingly, it can be said that generally the surveyed teachers had a high motivation in teaching language through the use of computers substantiated by the interview finding as well. This result is consistent with the study findings of Cox, et al. (1999), Nurul Atikah et al. (2006), Abdul Razak, and Sanmugam (2010), Perkmen, and Çevik (2010), and Li and Walsh (2011), in which the respondents were highly motivated to utilize computer technology in teaching purposes.

\subsection{Results Related to Question Three}

The Fourth Section of the questionnaire was designed to investigate English teachers' personality traits towards ICT usage in language teaching. The sample teachers were asked to describe their personality dimensions in computer application by responding to a total of 40 statements within the five subscales of the "Big Five" personality traits: extroversion; agreeableness; conscientiousness; openness; and neuroticism. Moreover, each trait comprises of 8 Likert-scale items ranging from 1 "Strongly disagree" to 5 "Strongly agree". Prior to analyzing the 5 personality scales, negative statements were reverse-coded.

Table 4 presents the mean, std. Deviation, minimum, maximum and range of scores for all the five personality traits. Generally, the overall mean value for the English teachers in the extroversion $(\mathrm{M}=3.77$ and $\mathrm{SD}=.73)$, agreeableness $(\mathrm{M}=3.56$ and $\mathrm{SD}=.49)$, conscientiousness $(\mathrm{M}=3.57$ and $\mathrm{SD}=.46)$ and openness $(\mathrm{M}=3.67$ and $\mathrm{SD}=.60)$ traits are fairly high. The overall mean value in the neuroticism trait $(\mathrm{M}=3.11$ and $\mathrm{SD}=.53)$ is moderate. In addition, the overall mean value for all five personality dimensions is $\mathrm{M}=3.54(\mathrm{SD}=.28)$ which shows a high mean score for the respondents personality characteristics towards ICT usage in teaching English classrooms. For further understanding of the sample teachers' personality towards using ICT, the teachers' view quotations are provided as follow:

“... Open to leave ideas and be flexible in teaching” (A1: Malay female)

“... Extrovert, but sometimes I can be introvert... more like to be an open person..." (A2: Malay female)

“... Open to everything and talk anything to anybody" (A3: Indian male)

The interview transcripts illustrated that the three interviewees were more open and extravert individuals towards using ICT. This finding strengthens the results found from the questionnaire analysis. As the descriptive data from the teachers' personality traits revealed, extroversion and openness reached the highest mean value in the "Big Five" personality traits towards ICT usage. The interview findings verify this result.

\subsection{Results Related to Question Four}

In order to address the fourth and fifth research questions, all the items were firstly summed for a single score and then Pearson correlation coefficients were computed. The results are presented in Table 5. The findings of the correlation analysis in relation to question four indicated that the surveyed teachers' motivation received a slightly moderate and positive relationship with ICT usage $(\mathrm{r}=.38, \mathrm{n}=89, \mathrm{p}<0.01)$. This result corresponded to the study of 
Cox, et al. (1999).

\subsection{Results Related to Question Five}

To address the fifth research question, Pearson correlation coefficient was utilized to calculate the relationship between teachers' personality traits and ICT usage (see Table 5.). The first trait is extroversion which refers to the confidence, sociability, gregarious, and optimism traits. Extraverts tend to have positive emotions, enjoy human interactions and contribute to develop team satisfaction (Watson and Clark 1984; McCrae and Costa 1987; Barrick, Stewart, Neubert, \& Mount 1998). As shown in Table 5, extroversion $(r=.315, n=89, p<0.01)$ received a slightly moderate and positive correlation with ICT usage by the surveyed teachers. This finding is compatible with Perkmen and Cevik's study (2010). In addition, this result is consistent with the Katz and Offer's (1991) study which found that more extraverted, stable, and tough minded teachers have more positive attitudes to use computer in classroom. As illustrated in table 8, the findings of all the other traits such as agreeableness $(\mathrm{r}=.084, \mathrm{n}=89, \mathrm{p}>0.05)$, conscientiousness $(r=-.073, n=89, p>0.05)$, openness $(r=.070, n=89, p>0.05)$, and neuroticism $(r=.014, n=89$, $\mathrm{p}>0.05$ ) were not statistically significant at the 0.05 confidence level in relation to ICT usage. In sum, the correlational coefficient of the personality total score $(\mathrm{r}=.200, \mathrm{n}=89, \mathrm{p}>0.05)$ did not show any significant relationship to ICT usage in the second language teaching.

\section{Conclusions}

This study examined the English teachers' personality and motivation towards the information and communication technology use in second language teaching practices. This study has contributed to the existing body of research regarding the computer technology integration in schools of Malaysia. The findings of the descriptive analysis concerning the first research question showed that English teachers have high $(\mathrm{M}=3.63, \mathrm{SD}=.46)$ levels of ICT usage. It seems that the Malaysian teachers use computer technology highly in their teaching. The findings also indicated that teachers use ICT for general software applications such as Internet, E-mail, presentation, word processing and office work. On the other hand, they have low level of ICT usage for specialized software applications such as authoring, graphics and simulations. These results were supported by the interview findings and in accordance with the findings of Lau and Sim's (2008) study. Overall, this finding offers that schools teachers require training in a wide range of computer technology skills to make full use of ICT in teaching processes.

In addition, the gained results of the study revealed that the surveyed teachers had a high motivation towards computer usage in teaching language which is substantiated by the interview findings. The findings of correlation analysis indicated that the surveyed teachers' motivation received a slightly moderate and positive $(\mathrm{r}=.38, \mathrm{n}=89$, $\mathrm{p}<0.01$ ) relationship with ICT usage. This result corresponded to the study of Cox, et al. (1999). They found several motivational factors were associated positively or negatively with IT usage by teachers. This result is also consistent with the study findings of Nurul Atikah et al. (2006), Abdul Razak, and Sanmugam (2010), Perkmen, and Çevik (2010), and Li and Walsh (2011), in which the respondents were highly motivated to utilize computer technology in their teaching purposes.

The mean score for the overall personality traits indicated a high mean value and the surveyed teachers were high extrovert, agreeable, conscientious and open characteristics and a moderate neurotic. The findings of the relationship between teachers' personality traits and ICT usage showed that extroversion has a slightly moderate and positive $(\mathrm{r}=.315, \mathrm{n}=89, \mathrm{p}<0.01)$ correlation with ICT usage by the surveyed teachers. This finding is compatible with the study results of Katz and Offer (1991) study Perkmen and Cevik (2010). Furthermore, the findings of the other traits such as agreeableness, conscientiousness, openness, and neuroticism were not statistically significant at the 0.05 confidence level in relation to ICT usage. This implies that ICT use has nothing to do with personality traits meaning that there should be no worries whether a teacher with any type of personality traits is probably in advantage for using the computer technology throughout his/her class practices. Although the debate still exists on the existence of difference in performance of learners/teachers who have diverse personality traits (Kiany, 1997; Stern, 1983), the study compatible with other studies indicate no such case.

\subsection{Implications of the Study}

The study results present some interesting implications and information to curriculum planners, teacher educators, and policy makers. Based on the findings of this study, most respondents used ICT highly. This could portray that the TESL students in their career can make use of ICT effectively for their teaching. This is promising and would imply that the Malaysia teachers can enhance their teaching through ICT use. Therefore, plans and programs are required by the curriculum planners, teacher educators, and policy makers not only to maintain this high level of ICT use, but also to attempt to enhance and develop it through the coming years.

In addition, having high motivation in computer use among the respondents of this research affirms the fact that 
motivation is pivotal as it is in many aspects of language learning. Also, it was proved that the higher motivation yields higher ICT use. The results of this study may imply that the higher motivation in ICT use of the respondent will direct them to better use of the ICT for improving English teaching. This may also affect the students in the classrooms to enhance their understanding of ICT use. Again, teacher educators and policy makers need to focus on this finding and try to maintain the existing high motivation as well as improving the motivation among those who still keep on having moderate or low motivation.

Although extroversion was shown to be a significant factor in better ICT use, in general, personality traits were shown not to be influential in determining the ICT use. This implies that ICT use has nothing to do with personality traits. Stakeholders need to keep this fact in mind that teachers with any particular type of personality traits are not in advantage for using the computer technology throughout his/her class practices over the others because no relation was proved throughout this study.

\subsection{Recommendations for Further Study}

The current study examined the English teachers' motivation and personality traits towards ICT usage. This study answered to the Saleem, Beaudry, and Croteau's (2011) call for evaluating the role of personality traits and motivation to use IT. Therefore, this research study provides some recommendations for further studies:

A survey method was used in this research. Hence, an experimental design addressing the limitations of this research is needed. Using observation may help to understand how and to what extent English teachers utilize ICT resources in teaching processes. Using a cross-sectional approach and a longitudinal study to strengthen the conclusions of this research is recommended. This study recommends comparing the personality traits of English teachers towards using ICT with teachers of other subjects.

\section{References}

Afshari, M., Bakar, K. A., Su Luan, W., Samah, B. A., \& Fooi, F. S. (2009). Factors affecting teachers' use of information and communication technology. International Journal of Instruction, 2(1), 77-104. http://dx.doi.org/10.1080/14759390600769722

Aydin, A. (1998). Sinif Yonetimi, Ani Yayincilik, Ankara. Cruickshank, D. L., Bainer, D. L., \& Metcalf, K. K. (1995). The Act of Teaching. New York: Mcgraw-Hill Inc.

Barrick, M. R., \& Mount, M. K. (1991). The big five personality dimensions and job performance: A meta-analysis. Personnel Psychology, 44, 1-26.

Barrick, M. R., Stewart, G. L., Neubert, M. J., \& Mount, M. K. (1998). Relating member ability and personality to work-team processes and team effectiveness. Journal of Applied Psychology, 83, 377-391.

Beck J. R. (1999). Jesus \& personality theory: Exploring the Five-Factor Model. Downers Grove, IL: Inter Varsity Press.

Boswood, T. (1997). New ways of using computers in language teaching (New Ways in Tesol Series II). California: Teachers of English to Speakers of Other Languages.

Chan, B. (2001). An Empirical Study of the Relationship Between Tutor's Personality and Teaching Effectiveness: Implications for Management of Tutors in Distance Education. International Conference on Offshore Education and Training in an e-Learning World, Australia.

Chong, C. K., Sharaf, H., \& Jacob, D. (2005). A study on the use of ICT in mathematics teaching. Malaysian Online Journal of Instructional Technology, 2(3), 43-51.

Costa, P. T., Jr., \& McCrae, R. R. (2000). Overview: Innovations in Assessment Using the Revised NEO Personality Inventory. Assessment, 7(4), 325-327.

Cox, M. J., Preston, C., \& Cox, K. What motivates teachers to use ICT? Paper presented at the British Educational Research Association (BERA), University of Sussex, Brighton. Brighton, September 1999.

Cuban, L. (2001). Oversold and Underused: Reforming Schools Through Technology. 1980-2000. Cambridge MA: Harvard University Press.

Denissen, J. J. A., \& Penke, L. (2008). Individual Reaction Norms Underlying the Five Factor Model of Personality: First Steps towards a Theory-Based Conceptual Framework. Journal of research in personality, 42, 1285-1302.

De Raad, B. (2000). The Big Five personality factors: The Psycho-lexical Approach to Personality. Germany: Hogrefe \& Huber Publishers.

Devaraj, S., Easley, J., \& Crant, M. (2008). How does personality matter? Relating the five-factor model to 
technology acceptance and use. Information Systems Research, 19(1), 93-105.

Downes, T., Arthur, L., Beecher, B. (2001). Effective learning environments for young children using digital resources: An Australian perspective. Information Technology in Childhood Education, 1, 129-143.

Dusick, D. M. (1998). What social cognitive factors influence faculty members' use of computers for teaching? A literature review. Journal of Research on Computing in Education, 31(2), 123-138.

Efaw, J., Hampton, S., Martinez, S., \& Smith, S. (2004). Miracle or Menace: Teaching and Learning with Laptop Computers in the Classroom. Educause Quarterly, 27(3), 1-8.

Furnham, A., Dissou, G., Sloan, P., \& Chamorro-Premuzic, T. (2007). Personality and intelligence in business people: A Study of two personality and two intelligence measures. Journal of Business Psychology, 22, 99-109.

Gholami, Reza, Nooreen Noordin, \& Ghazali, Mustapha. (in press). EAP Writing and Speaking Needs of EFL Students in ESL Contexts. Pertanika, Journal of Social Sciences and Humanities. JSSH. (Submitted in 2011).

Goldberg, L. R. (1981). Language and individual differences: The search for universals in personality lexicons. In Review of personality and social psychology (ed. L. Wheeler), Vol. 2, pp. 141-165. Beverly Hills, CA: Sage.

Hamburger, Y. A., \& Ben-Artzi, E. (2000). The relationship between extroversion and neuroticism and the different uses of the Internet. Computers in Human Behaviour. 16(4), 441-449. http://dx.doi.org/10.1016/S0747-5632(00)00017-0

Hudiburg, R. A., Pashaj, I., \& Wolfe, R. (1999). Preliminary Investigation of Computer Stress and the Big-Five Personality Factors. Psychological Reports, 85, 473-480.

John, O. P. (1990). The "Big Five" factor taxonomy: Dimensions of personality in the natural language and questionnaires. In Pervin, L. A. (eds), Handbook of personality: Theory and research (66-100). New York: Guilford Press.

Judge, T. A., Higgins, C. A., Thoresen, C. J., \& Barrick, M. R. (1999). The Big Five personality traits, general mental ability, and career success across the life span. Personnel Psychology, 52(3), 621-652.

Judge, T. A., \& Bono, J. E. (2000). Five factor model of personality and transformational leadership. Journal of Applied Psychology, 85(5), 751-765.

Judge, T. A., Thoresen, C. J., Bono, J. E., \& Patton, G. K. (2001). The job satisfaction-job performance relationship: A qualitative and quantitative review. Psychological Bulletin, 127, 376-407.

Katz, J. Y., \& Offir, B. (1991). The relationship between personality and computer attitudes of Israeli teachers. Education and Computing, Volume 7, Issues 3-4, 249-252.

Katz, J. Y. (1992). Toward a personality profile of successful computer-using teacher. Educational Technology, 32, $39-40$.

Kiany, G. (1997). English Proficiency \& Academic Achievement in Relation to Extroversion-Introversion: A Preliminary Study. [Online] Available: www.essex.ac.uk:http://www.essex.ac.uk/linguistics/publications/egspll/ volume_1/pdf/REZAIKIANY.pdf (january 2010)

Kidd, Terry T., \& Song, H. (2005). The Motivating Factors that Lead Teachers to the Success Adoption and Implementation of Computer and Multimedia Technology? In Proceedings of World Conference on E-Learning in Corporate, Government, Healthcare, and Higher Education 2005 (pp. 1671-1674). Norfolk, VA: AACE.

Kleiman, G. (2000). Myth and realities about technology inK-12 schools. The digital classroom: How technology is changing the way we teach and learn. Leadership and the New Technologies. [Online] Available: http://www.edc.org/LNT/news/Issue14/feature1.htm (March 29, 2010)

Lau, B. T., \& Sim, C. H. (2008). Exploring the extent of ICT adoption among secondary school teachers in Malaysia. International Journal of Computing and IT Research, 2(2), 19-36.

Lee, L. G. (2000). Implementation of smart teaching and learning at pilot smart schools in Kedah and Perlis. Proceeding at the National Seminar of Educational Research. November, 8-11, 2002. Hotel City Bayview, Pulau Langkawi.

Li, L., \& Walsh, S. (2011). Technology uptake in Chinese EFL classes. Language Teaching Research, 15, 99-125. http://dx.doi.org/10.1177/1362168810383347

Lounsbury, J. W., Steel, R. P., Loveland, J. M., \& Gibson, L. W. (2004). An investigation of personality traits in relation to adolescent school absenteeism. Journal of Youth and Adolescence, 33(5), 457-466. 
Lumley, D. (1991). Improving Student Motivation. Electronic Learning, 11(3), 14. Retrieved May 3, 2010, from ProQuest database.

Marcinkiewicz, H. R. (1993). Computers and teachers: Factors influencing computer use in the classroom. Journal of Research on Computing in Education, 26, 220-237.

Marcinkiewicz, H. R. (1996). Motivation and teachers' computer use. Proceedings of Selected Research and Development Presentations at the 1996 National Convention of the Association for Educational Communications and Technology (8th, Indianapolis, IN, 1996).

McCrae, R. R., \& Costa, P. T. (1991). Adding Liebe und Arbeit: The full five-factor model and well-being. Personality and Social Psychology Bulletin, 17, 227-232.

McNabb, M. (1999). Critical issues in evaluating the effectiveness of technology. [Online] Available: www.ed.gov/Technology/TechConf/1999/confsum.html

Melor Md Yunus. (2007b). Factors affecting the use of Information Communication Technologies in teaching English as a second language in Malaysia. PhD Dissertation, Faculty of Social Sciences and Law, UK: University of Bristol.

Nurul Atikah Abdullah, Mohamad Jafre Zainol Abidin, Wong Su Luan, \& Hanafi Atan. (2006). The Attitude and Motivation of English Language Teachers towards the Use of Computers. Malaysian Online Journal of Instructional Technology, 3(1), 57-67.

Passey, D., \& Samways, B. (1997). Information Technology- Supporting Change through Teacher Education. London: Chapman and Hall.

Perkmen, S., \& Çevik, D. B. (2010). Relationship between Pre-Service Music Teachers' Personality and Motivation for Computer-Assisted Music Instruction. Music Education Research, 12(4), 415-425. http://dx.doi.org/10.1080/14613808.2010.519768

Pusack, J., \& Otto, S. (1997). “Taking control of multimedia”. In M. Bush \& R. Terry (eds.), Technology-Enhanced Language Learning (pp. 1- 46). Lincolnwood: National Textbook Company.

Ross, C., Orr, S. E., Sisic, M., Arseneault, J. M., Simmering, M. G., \& Orr, R. R. (2009). Personality and motivations associated with Face book use. Computers in Human Behaviour, 25, 578-586.

Ryckman, R. (2004). Theories of Personality. Belmont, California: Thomson/Wadsworth.

Saleem, H., Anne Beaudry, A., \& Croteau, A. (2011). Antecedents of computer self-efficacy: A study of the role of personality traits and gender. Computers in Human Behaviour. http://dx.doi.org/10.1016/j.chb.2011.04.017

Smart School Task Force. (1997). Smart Schools in Malaysia: The Way to the Future. Kuala Lumpur: Ministry of Education.

Smith, B., \& Munday, R. (1995). Prediction of teachers' use of technology based on personality type. Journal of Instructional Psychology, 22(3), 281-286.

Stern, H. (1983). Fundamental Concepts in Language Teaching. Oxford : Oxford University Press.

Teh, P., Yong, C., Chong, C., \& Yew, S. (2011). Do the Big Five Personality Factors affect knowledge sharing behaviour? A study of Malaysian universities. Malaysian Journal of Library \& Information Science, 16(1), 47-62.

The Malaysian Dream: Vision $2020 . \quad$ AOnline] http://www.themalaysiandream.net/documents/12/vision-2020

Tonelson, S. W. (1981). The Importance of Teacher Self-Concept to Create a Healthy Psychological Environment for Learning. Education, 102, 96-100.

Watson, D., \& Clark, L. A. (1984). Negative Affectivity: The disposition to experience aversive emotional states. Psychological Bulletin, 96, 465-490.

Watson, D., \& Clark, L. A. (1997). Extroversion and its positive emotional core. In Hogan, R., Johson, J., Briggs, S. (Eds.), Handbook of personality psychology (pp.767-793). San Diego, CA: Academic Press.

Yusof, J., Taib, I. S., \& Adnan, A. H. (2010). ICT take-up rate amongst language teachers in Malaysian private schools. Paper presented at the 3rd Malaysia International Conference on Academic Strategies in English Language Teaching, Kuala Lumpur. Dec. 2010. 
Table 1. Means, Std. Deviations of the Respondents' Level of ICT Use

\begin{tabular}{|c|c|c|c|c|c|}
\hline Item & Mean & SD & Min & Max & $\begin{array}{c}\text { Percentages } \\
(\%)\end{array}$ \\
\hline Spreadsheets & 3.15 & 1.01 & 1 & 5 & 32.6 \\
\hline Graphics & 2.67 & 1.10 & 1 & 5 & 10.1 \\
\hline Presentation & 4.35 & .74 & 2 & 5 & 86.6 \\
\hline Database program & 2.79 & 1.08 & 1 & 5 & 11.2 \\
\hline CD-ROM, DVD & 3.68 & 1.05 & 2 & 5 & 60.6 \\
\hline Internet & 4.58 & .61 & 3 & 5 & 93.3 \\
\hline Discipline-specific programs & 3.83 & 1.06 & 1 & 5 & 65.2 \\
\hline Authoring & 2.64 & .96 & 1 & 5 & 10.1 \\
\hline E- mail & 4.65 & .62 & 3 & 5 & 92.1 \\
\hline Word processing & 4.40 & .82 & 2 & 5 & 85.4 \\
\hline Drill and practice & 3.41 & 1.04 & 1 & 5 & 51.7 \\
\hline Office work & 4.10 & .96 & 2 & 5 & 76.4 \\
\hline Multimedia application & 3.71 & .98 & 2 & 5 & 58.4 \\
\hline Simulations and games & 2.80 & 1.07 & 1 & 5 & 24.7 \\
\hline Overall results & 3.63 & .46 & 2.71 & 4.79 & \\
\hline
\end{tabular}

Table 2. Mean Value

\begin{tabular}{cc}
\hline Mean Value & Level \\
\hline $4.50-5.00$ & Very High \\
$3.50-4.49$ & High \\
$2.50-3.49$ & Moderate \\
$1.50-2.49$ & Low \\
$1.00-1.49$ & Very Low \\
\hline
\end{tabular}

Table 3. Motivation to Use ICT

\begin{tabular}{cccccc}
\hline Item & Mean & SD & Min & Max & Percentage (\%) \\
\hline M1 & 4.33 & .72 & 1 & 5 & 93.2 \\
M2 & 3.96 & .91 & 1 & 5 & 76.4 \\
M3 & 4.43 & .73 & 1 & 5 & 93.2 \\
M4 & 4.14 & .79 & 1 & 5 & 83.1 \\
M5 & 4.20 & .86 & 1 & 5 & 83.1 \\
M6 & 3.96 & .87 & 1 & 5 & 75.3 \\
M7 & 4.21 & .74 & 1 & 5 & 88.8 \\
M8 & 4.05 & .87 & 1 & 5 & 82.1 \\
M9 & 3.97 & .89 & 1 & 5 & 78.7 \\
M10 & 3.91 & .79 & 1 & 5 & 74.1 \\
M11 & 4.00 & .76 & 1 & 5 & 76.4 \\
M12 & 3.64 & 1.02 & 1 & 5 & 64.0 \\
M13 & 3.95 & .82 & 1 & 5 & 76.4 \\
Overall & 4.06 & .60 & 5 & \\
\hline
\end{tabular}


Table 4. Descriptive Statistics for Personality Traits

\begin{tabular}{|c|c|c|c|c|c|}
\hline Trait & Mean & SD & Min & $\operatorname{Max}$ & Range \\
\hline Extroversion & 3.77 & .73 & 1.63 & 5.0 & 3.38 \\
\hline Agreeableness & 3.56 & .49 & 2.25 & 5.0 & 2.75 \\
\hline Conscientiousness & 3.57 & .46 & 2.25 & 4.75 & 2.50 \\
\hline Openness & 3.67 & .60 & 1.88 & 5.0 & 3.13 \\
\hline Neuroticism & 3.11 & .53 & 1.50 & 4.0 & 2.50 \\
\hline Overall & 3.54 & .28 & 2.90 & 4.25 & 1.35 \\
\hline
\end{tabular}

Table 5. Correlations of the Study Variables with ICT Usage

\begin{tabular}{|c|c|c|c|c|c|c|c|c|}
\hline Variable & ICT & M & $\mathbf{P}$ & $\mathbf{E}$ & $\mathbf{A}$ & $\mathrm{C}$ & $\mathbf{O}$ & $\mathbf{N}$ \\
\hline ICT & 1 & & & & & & & \\
\hline $\mathbf{M}$ & $.389 * *$ & 1 & & & & & & \\
\hline $\mathbf{P}$ & .200 & .208 & 1 & & & & & \\
\hline $\mathbf{E}$ & $.315^{* *}$ & $.212 *$ & $.644^{* *}$ & 1 & & & & \\
\hline $\mathbf{A}$ & .084 & .139 & $.498^{* *}$ & .089 & 1 & & & \\
\hline $\mathrm{C}$ & -.073 & -.044 & $.610^{* *}$ & .084 & $.434 * *$ & 1 & & \\
\hline $\mathbf{O}$ & .070 & -.062 & $.621^{* *}$ & $.223^{*}$ & .058 & $.464^{* *}$ & 1 & \\
\hline $\mathbf{N}$ & .014 & $.251 *$ & .126 & -.041 & -.145 & $-.262 *$ & $-.216^{*}$ & 1 \\
\hline
\end{tabular}

Note: Dependent Variable: ICT Usage

\section{$\mathrm{M}=$ Motivation}

$\mathrm{P}=$ Personality $; \mathrm{E}=$ Extroversion; $\mathrm{A}=$ Agreeableness $; \mathrm{C}=$ Conscientiousness $; \mathrm{O}=$ Openness; $\mathrm{N}=$ Neuroticism;

**. Correlation is significant at the 0.01 (2-tailed). $\mathrm{p}<.01$

*. Correlation is significant at the 0.05 (2-tailed). $\mathrm{p}<.05$ 